\title{
Encapsulation of E. coli phage ZCEC5 in chitosan-alginate beads as a delivery system in phage therapy
}

Abdallah S. Abdelsattar ${ }^{1,2}$, Fatma Abdelrahmann ${ }^{1}$, Alyaa Dawoud ${ }^{1}$, Ian F. Connerton ${ }^{3}$ and Ayman El-Shibiny ${ }^{1,4^{*}}$

\begin{abstract}
Bacteriophages can be used successfully to treat pathogenic bacteria in the food chain including zoonotic pathogens that colonize the intestines of farm animals. However, harsh gastric conditions of low pH and digestive enzyme activities affect phage viability, and accordingly reduce their effectiveness. We report the development of a natural protective barrier suitable for oral administration to farm animals that confers acid stability before functional release of bead-encapsulated phages. Escherichia coli bacteriophage ZSEC5 is rendered inactive at pH 2.0 but encapsulation in chitosan-alginate bead with a honey and gelatin matrix limited titer reductions to $1 \log _{10} \mathrm{PFU} \mathrm{mL} \mathrm{mL}^{-1}$. The encapsulated phage titers were stable upon storage in water but achieved near complete release over $4-5 \mathrm{~h}$ in a simulated intestinal solution $\left(0.1 \%\right.$ bile salt, $0.4 \%$ pancreatin, $\left.50 \mathrm{mM} \mathrm{KH}_{2} \mathrm{PO}_{4} \mathrm{pH} 7.5\right)$ at $37^{\circ} \mathrm{C}$. Exposure of E. coli O157:H7 to the bead-encapsulated phage preparations produced a delayed response, reaching a maximal reductions of 4.2 to $4.8 \log _{10} \mathrm{CFU} \mathrm{mL} \mathrm{m}^{-1}$ after $10 \mathrm{~h}$ at $37^{\circ} \mathrm{C}$ under simulated intestinal conditions compared to a maximal reduction of $5.1 \log _{10} \mathrm{CFU} \mathrm{mL} \mathrm{m}^{-1}$ at $3 \mathrm{~h}$ for free phage applied at $\mathrm{MOI}=1$. Bead-encapsulation is a promising reliable and cost-effective method for the functional delivery of bacteriophage targeting intestinal bacteria of farm animals.
\end{abstract}

Keywords: E. coli, Bacteriophage, Biocontrol, Phage encapsulation

\section{Introduction}

Antibiotic resistance is a serious public health problem worldwide. Commercially available antibiotics are becoming less effective as resistance rates rise over time (Akinkunmi and Lamikanra 2015). Accordingly, many intestinal bacterial infections are showing greater virulence and/or persistence (Munot and Kotler 2016). Such resistance phenotypes are generally attributed to the misuse of antibiotics, which have increased invulnerability to hamper the treatment of infection, and indirectly increase the rate of mortality. Antibiotic use and resistance presents a real dilemma for developed and developing countries (Fortini et al. 2011; Pavlickova et al. 2015; Wellington et al. 2013).

\footnotetext{
*Correspondence: aelshibiny@zewailcity.edu.eg

${ }^{1}$ Center for Microbiology and Phage Therapy, Zewail City of Science and Technology, October Gardens, 6th of October City, Giza 12578, Egypt Full list of author information is available at the end of the article
}

Enterohemorrhagic Escherichia coli $\mathrm{O} 157: \mathrm{H} 7$ is a zoonotic pathogen frequently isolated from healthy cattle and other farm animals. The organism causes human gastroenteritis, haemorrhagic colitis, and can lead to the development of hemolytic uremic syndrome (Karmali et al. 1983). Isolates often show multi-drug resistant phenotypes with reports indicating resistance to 14 different antibiotics (Verstraete et al. 2013). E. coli O157:H7 can be acquired from direct contact with infected animals (Belongia et al. 1991), or through cross-contamination of raw materials in the preparation of foods, or through the consumption of contaminated food (Neil et al. 2012). E. coli $\mathrm{O} 157: \mathrm{H7}$ remains a threat to public health.

Bacteriophages represent an alternative treatment for the control of bacterial contamination in foods as well as the control of bacterial infections in man and animals due to their abilities to specifically target bacterial host cells and self-replicating nature (Jassim and Limoges 2014; Summers 2001; Taha et al. 2018). Research has demonstrated the use of bacteriophages to reduce E. coli 
O157:H7 in the gastrointestinal tracts of mice (Tanji et al. 2005) and sheep (Bach et al. 2003; Raya et al. 2011), and on the surface of the meat (El-Shibiny et al. 2017; O'Flynn et al. 2004). Studies also suggest phage application could decrease the mortality rate of poultry on infected farms (Xie et al. 2005).

The oral application of phage in human trials has not reported any adverse effects (Bruttin and Brussow 2005; Sarker et al. 2012; McCallin et al. 2013). However, the oral application of phage is not without difficulty due to exposure to gastric juice (GJ) during stomach transit, which may affect the viability of bacteriophages (Tóthová et al. 2012). In light of the above, phage encapsulation techniques have provided a protective delivery technique for phage against the harsh conditions of GJ with minimal phage loss (Choińska-Pulit et al. 2015). Previous publications have highlighted the possibility of using food-grade alginate and chitosan as biomaterials for the microencapsulation of bacteriophages ( $\mathrm{Ma}$ et al. 2008, 2012; Tang et al. 2013; Kim et al. 2015; Colom et al. 2017). Alginate is considered a good system for phage encapsulation because of its ability to resist acidity, and to control and sustain the release of live products to the gut such as probiotic bacteria and bacteriophages (Gbassi et al. 2009; Lee and Heo 2000). Alginate polysaccharide can be obtained naturally from bacteria and algae, which crosslinks to form a gel with calcium (Lee and Heo 2000). Chitosan is a natural polymer that can be obtained from crustaceans with inherent bacteriostatic and antifungal properties (Mcknight et al. 1988). Accordingly, it is inappropriate for use as a core solution for capsules (Sudarshan et al. 1992), but can be used as a coating material in pharmaceutical applications due to its solubility in acid conditions coupled with excellent biodegradable and biocompatible properties (Allan et al. 1984). Retention of the bead structure and preservation of the phage payload requires that the inner matrix have suitable aqueous viscosity. To this end formulations with gelatin to improve the functional properties of the beads (Gbassi and Vandamme 2012), and honey to stabilize the phage (Oliveira et al. 2017) were explored. In general, the encapsulation process could protect phages against harsh conditions such as acidity and oxidation, control of the release of the active agents, facilitate their diffusion and improve effectiveness (Ghosh et al. 2006; Jyothi et al. 2010; Tang et al. 2013). The objective of this study was to develop a stable chitosan-alginate bead delivery system for the controlled release of bacteriophages. We have examined the protection afforded by the beads for E. coli O157:H7 bacteriophages under simulated GI conditions and storage conditions with respect to retention of bacteriophage titers. We demonstrate that the beads are an effective delivery agent for phage with advantages in reducing $E$. coli $\mathrm{O} 157: \mathrm{H} 7$ viable counts under simulated intestinal conditions.

\section{Materials and methods}

Bacterial strain and culture conditions

Studies were conducted using the bacterial host E. coli O157:H7 NCTC 12900 (the kind gift of Dr. Elizabeth Kutter). Bacteriophage were routinely propagated on E. coli O157:H7 NCTC 12900. Stocks were maintained in $20 \%(\mathrm{v} / \mathrm{v})$ glycerol at $-80{ }^{\circ} \mathrm{C}$. In the following experiments, bacterial strains were grown on tryptic soy agar (TSA; Oxoid, England) overnight and infections carried out in Tryptic Soya Broth (TSB; Oxoid, England) in Erlenmeyer flasks at $37{ }^{\circ} \mathrm{C}$ and $120 \mathrm{RPM}$ to reach OD600 approximately 0.3 .

\section{Bacteriophage isolation and enumeration}

Bacteriophages were isolated by us from environmental and sewage samples against E. coli O157:H7 NCTC 12900. Each sample $(\sim 1 \mathrm{~mL})$ was mixed with TSB containing the bacterial host and incubated overnight at $37{ }^{\circ} \mathrm{C}$ to amplify any available phage. After incubation, each sample was serially diluted and spotted on to bacterial lawns of E. coli O157:H7 NCTC 12900 to identify any bacteriophages by checking the production of plaques in the bacterial lawn by the 2nd day. A single plaque from a positive agar plate was purified by repeated single plaque isolation using sterile micropipette tips (Adams 1959). All isolated bacteriophages were amplified in TSB and the lysate was centrifuged at $6400 \times g$ for $15 \mathrm{~min}$ at $4{ }^{\circ} \mathrm{C}$ to remove the bacterial cells and debris (Marcó et al. 2012). The supernatant was then centrifuged at $15,300 \times g$ at $4{ }^{\circ} \mathrm{C}$ for $1 \mathrm{~h}$ to obtain the precipitated pellet of bacteriophages. Bacteriophage pellets were re-suspended in SM buffer

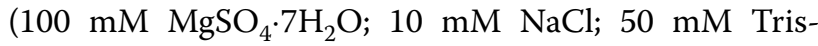
$\mathrm{HCl} \mathrm{pH} \mathrm{7.5)} \mathrm{and} \mathrm{filtered} \mathrm{using} 0.22 \mu \mathrm{m}$ syringe filters (Chromtech, Taiwan). The purified bacteriophage stock was then enumerated as plaque-forming unit (PFU) using double-agar overlay plaque assays (Kropinski et al. 2009), and stored in SM buffer at $4{ }^{\circ} \mathrm{C}$ prior to use (Lillehaug 1997). The phage isolate ZCEC5 used in this study can be obtained from Biomedical Sciences Program, Zewail City of Science and Technology, 12578 Giza, Egypt.

\section{Characterization of bacteriophage ZCEC5}

Bacteriophage ZCEC5 was examined using transmission electron microscopy at the National Research Center (Cairo, Egypt) as previously described (Atterbury et al. 2003). Briefly, fixed phages on Pioloform grids using glutaraldehyde were negatively stained with $0.5 \%$ uranyl acetate. After drying, the specimens were examined using a JEOL 100CX transmission electron microscope. 
Genomic DNA was extracted from a lysate of phage ZCEC5 $\left(10^{10} \mathrm{PFU} \mathrm{mL}^{-1}\right)$ treated with proteinase $\mathrm{K}$ $\left(100 \mu \mathrm{g} \mathrm{mL}^{-1}\right.$ in $10 \mathrm{mM}$ EDTA at $\mathrm{pH}$ 8) before purification by the Wizard DNA kit (Promega, UK) according to the manufacturer's instructions. The genome DNA of phage ZCEC5 was sequenced from libraries prepared using the Illumina tagmentation protocol on the MiSeq platform. The data was composed of 0.52 million pairedend sequence reads with read lengths of approximately $250 \mathrm{bp}$. The data was de novo assembled using CLC Genomics Workbench version 10.0.1 (Qiagen, Aarhus, Denmark). The open reading frames (ORFs) were predicted from PHASTER (Arndt et al. 2016). The genome DNA sequence appears in GenBank under the Accession Number MK542015.

\section{Encapsulation of bacteriophages}

Encapsulated bacteriophages were prepared using a chitosan-alginate coating shell (Fig. 1). Four matrices were prepared to produce the beads for study. The matrices for beads 1 and 2 were prepared by suspending bacteriophages in either $0.3 \%$ commercial honey and $0.25 \%$ gelatin or $3 \%$ honey to $2.5 \%$ gelatin, respectively. The matrix for bead 3 was prepared by suspending bacteriophages in $50 \mathrm{mM}$ Tris- $\mathrm{HCl} \mathrm{pH} \mathrm{7.4,} \mathrm{while} \mathrm{the} \mathrm{matrix} \mathrm{for} \mathrm{beads} 4$ was prepared by suspending bacteriophages in $0.01 \%$ gelatin, $0.05 \%$ honey, $0.15 \mathrm{M} \mathrm{NaCl}$ and $10 \mathrm{mM} \mathrm{MgSO}_{4} \cdot 7 \mathrm{H}_{2} \mathrm{O}$. Each type of matrix was mixed with $1.5 \%$ sodium alginate and then extruded into a $100 \mathrm{mM} \mathrm{CaCl}$, solution using a syringe before it was washed with distilled water after $30 \mathrm{~min}$. The prepared Ca-alginate beads were coated with chitosan applied in a chitosan $(0.4 \%)$-acetate $(100 \mathrm{mM})$

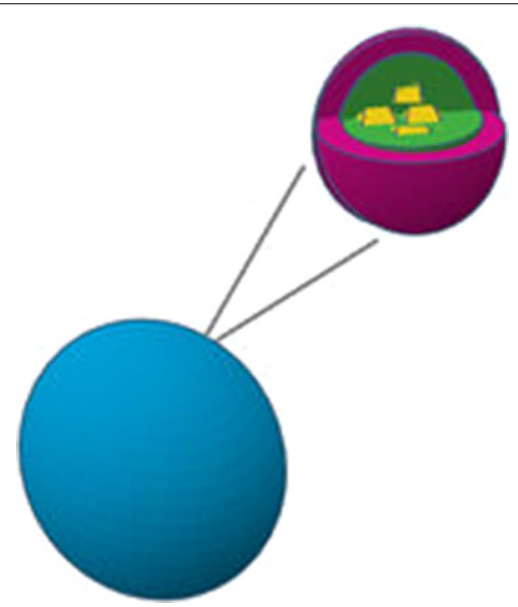

Fig. 1 Representation of the bead encapsulation components in cross-section. The blue color refers to the chitosan, purple the Ca-alginate, green the internal matrix and yellow represents the bacteriophage buffer solution $(\mathrm{pH} 4.2)$ for $30 \mathrm{~min}$. The beads were washed with distilled water and stored at $4{ }^{\circ} \mathrm{C}$ prior to use.

\section{Bacteriophage stability and release under simulated intestinal conditions}

The stability of encapsulated phages in simulated intestinal conditions was tested by preparing an artificial intestinal juice by dissolving $0.1 \%$ bile salt and $0.4 \%$ pancreatin (Sigma-Aldrich, MO, USA) in $50 \mathrm{mM} \mathrm{KH}_{2} \mathrm{PO}_{4} \mathrm{pH} 7.5$ (Kim et al. 2015). The beads of encapsulated bacteriophages at $2 \times 10^{7} \mathrm{PFU} \mathrm{mL} \mathrm{mL}^{-1}$ were incubated in simulated intestinal juice for $6 \mathrm{~h}$ at $37{ }^{\circ} \mathrm{C}$ with agitation. The free bacteriophage titer was determined using double-agar overlay plaque assays as described above.

\section{Acid stability assay}

The stability of encapsulated bacteriophages (beads) at the digestive system $\mathrm{pH}$ ranges was evaluated in $0.5 \%$ $\mathrm{NaCl}$ solution adjusted to different $\mathrm{pH}$ values $(2,2.5,3,4$ and 7) by the addition of $1 \mathrm{M} \mathrm{HCl}$ solutions. Beads were incubated in solutions of various $\mathrm{pH}$ for $60 \mathrm{~min}$ at $37^{\circ} \mathrm{C}$. After washing with distilled water, beads were incubated at $37^{\circ} \mathrm{C}$ for $60 \mathrm{~min}$ in a dissolving buffer solution $(50 \mathrm{mM}$ sodium citrate, $0.2 \mathrm{M}$ sodium bicarbonate and $50 \mathrm{mM}$ Tris- $\mathrm{HCl}$ at $\mathrm{pH}$ 7.3) (Liu et al. 2002), and the titers of the released bacteriophages determined using the doubleagar overlay plaque assays.

\section{Thermal stability assay}

The stability of encapsulated and non-encapsulated bacteriophages over a range of temperatures was evaluated by incubating phage suspensions in SM buffer at 25,40 , 60 and $80^{\circ} \mathrm{C}$ for $60 \mathrm{~min}$. To detect the protective effect of matrices against thermal conduction, the encapsulated and non-encapsulated bacteriophage were exposed to $80^{\circ} \mathrm{C}$ and samples were taken at $0,30,180 \mathrm{~s}$ intervals to detect the change in phage titer upon sudden temperature alteration. The titers of released bacteriophages were determined using the double-agar overlay plaque assays.

\section{Examination of bead morphology}

Encapsulated bacteriophages samples were investigated using a Trinocular Zoom Stereo microscope (Meiji Techno, EMZ-13TR).

\section{Diffusion properties of stored encapsulated bacteriophages}

Encapsulated bacteriophages were stored in flasks containing $200 \mathrm{~mL}$ of distilled water at $4{ }^{\circ} \mathrm{C}$. Samples of water were collected at various time points to determine the phage titers released using double-agar overlay plaque assays. 


\section{Lytic activity assay}

Encapsulated and non-encapsulated bacteriophage were tested for their lytic activity against $E$. coli O157:H7 NCTC 12900 by incubating each type of beads with $E$. coli in intestinal buffer at $37{ }^{\circ} \mathrm{C}$ with agitation at $120 \mathrm{rpm}$. The infection was performed at $\mathrm{MOI}=1$ and samples were collected after 3, 6 and $10 \mathrm{~h}$ of incubation for analysis.

\section{Statistical analysis}

All statistical analyses were carried out in triplicates. In this study, the Student's t-test and one-way ANOVA were used as statistical analysis test. The significance level was $p<0.05$. Data were analyzed using GraphPad PRISM version 5.01 for Windows (GraphPad Software, La Jolla, USA).

\section{Results}

\section{Bead morphology of the encapsulated bacteriophage preparations}

The morphological characteristics of the ZCEC5 phage-encapsulated beads were determined by inverted microscopy. Beads 1, 2 and 3 appeared spherical shape with mean diameters of $2.38 \pm 0.14,2.8 \pm 0.11$ and $2.33 \pm 0.12 \mathrm{~mm}$, respectively (Fig. $2 \mathrm{a}-\mathrm{c}$ ). Bead preparation $4(0.01 \%$ gelatin, $0.05 \%$ honey, $0.15 \mathrm{M} \mathrm{NaCl}$ and $10 \mathrm{mM} \mathrm{MgSO} \cdot 7 \mathrm{H}_{2} \mathrm{O}$ ) appeared non-uniform and irregular in shape (Fig. 3d), and was withdrawn from further experiments.

\section{Assessing leakage of encapsulated bacteriophages upon storage}

To determine the retention and stability of the encapsulated bacteriophages, beads were stored in distilled water at $4{ }^{\circ} \mathrm{C}$ and samples collected every day for 8 days and after 8 weeks of storage. Over the course of the experiment, no phage release was observed under the storage conditions.

\section{Release rate of encapsulated bacteriophages under stimulated intestinal conditions}

The bacteriophage release properties of the beads were measured after incubation in simulated gastrointestinal fluid (Fig. 3). The beads performed similarly producing titers in the range of 5.3 to $5.8 \log _{10}$ PFU mL ${ }^{-1}$ after $1 \mathrm{~h}$ incubation and achieving 7.4 to $7.5 \log _{10} \mathrm{PFU} \mathrm{mL}^{-1}$ after $5 \mathrm{~h}$ of incubation that approximates to full release of the matrix titer.
Lytic activity of non-encapsulated and encapsulated bacteriophages

The lytic activities of non-capsulated and encapsulated bacteriophages were determined against $E$. coli O157:H7 NCTC 12900 over 3, 6 and $10 \mathrm{~h}$ in simulated intestinal conditions at $\mathrm{MOI}=1$ (Fig. 4a). Nonencapsulated ZCEC5 showed maximal reductions in the viable count of E. coli O157:H7 NCTC 12900 of $5.1 \log _{10} \mathrm{CFU} \mathrm{mL} \mathrm{mL}^{-1}$ after $3 \mathrm{~h}$ and declined upon increasing the incubation time under the simulated intestinal conditions. Conversely, bead-encapsulated bacteriophages exhibit a delay in the observed reduction of $E$. coli O157:H7 NCTC 12900 that is commensurate with the cumulative release of bacteriophage ZCEC5 over time. After $10 \mathrm{~h}$ maximal reductions for the beadencapsulated treatments ( 4.2 to $4.8 \log _{10} \mathrm{CFU} \mathrm{mL} \mathrm{m}^{-1}$ ) were comparable to that of free phage at $3 \mathrm{~h}$ (Fig. 4a). Host infection in gastrointestinal fluid lead to a 100fold amplification of the bead-encapsulated phages over the initial titer of $7 \log _{10}$ PFU mL $\mathrm{mL}^{-1}$ at $10 \mathrm{~h}$, compared to tenfold recorded for free ZCEC5 phage infection (Fig. 4b).

\section{Acid and thermal acid stability of bead-encapsulated phage}

The stability of the bead-encapsulated bacteriophages in comparison to non-encapsulated bacteriophages were evaluated at acidic $\mathrm{pH}$ values, $\mathrm{pH} 2,2.5,3$ and 4 over $1 \mathrm{~h}$ at $37^{\circ} \mathrm{C}$ (Fig. 5b). The viability of non-encapsulated bacteriophages at pH 2 was measured after $30 \mathrm{~s}, 5 \mathrm{~min}$ and $10 \mathrm{~min}$, where their titers were observed to decrease by $2 \log _{10}$ PFU mL $\mathrm{mL}^{-1}$ after $30 \mathrm{~s}$ before falling below the detection limit $\left(3 \log _{10}\right.$ PFU mL $\left.\mathrm{m}^{-1}\right)$ after $10 \mathrm{~min}$. The viability of the bead-encapsulated phages were tested after $1 \mathrm{~h}$ incubation at the $\mathrm{pH}$ indicated at $37^{\circ} \mathrm{C}$ for $60 \mathrm{~min}$ in a dissolving buffer solution to release the encapsulated bacteriophages. Bead-encapsulation of bacteriophages has a protective effect against acid stress with approximately a $1 \log _{10}$ PFU reduction observed at $\mathrm{pH} 2$ compared to complete inactivation of the free phage. The matrix formulation of bead preparation 3 containing higher concentrations of glycerol and honey provided the greatest protection against low $\mathrm{pH}$ with no significant difference in the titer recovered post treatment at $\mathrm{pH} 3$.

The role of each matrix component in conferring thermal protection was investigated by determining the phage titers released from the beads after 0.5, 1 and 3 min of heat treatment at $80^{\circ} \mathrm{C}$ (Fig. 5a). Phage encapsulated in the matrix formulations of beads 1 and 2 containing honey and glycerol were more resistant to the heat treatment (titer reductions of 0.8 to $1 \log _{10}$ PFU mL ${ }^{-1}$ ) than free phage (titer reduction $2.2 \pm 0.22 \log _{10}$ PFU) or 


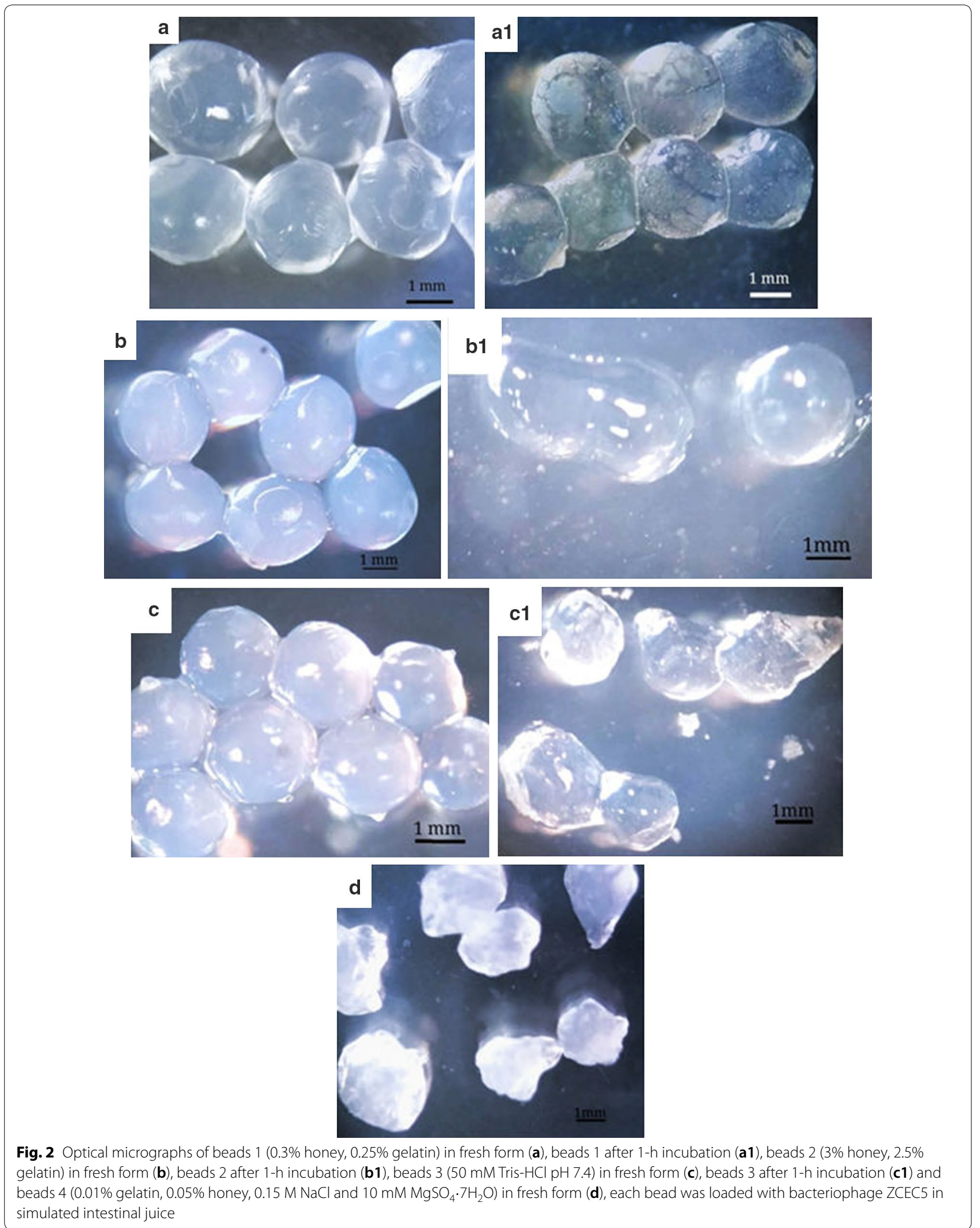




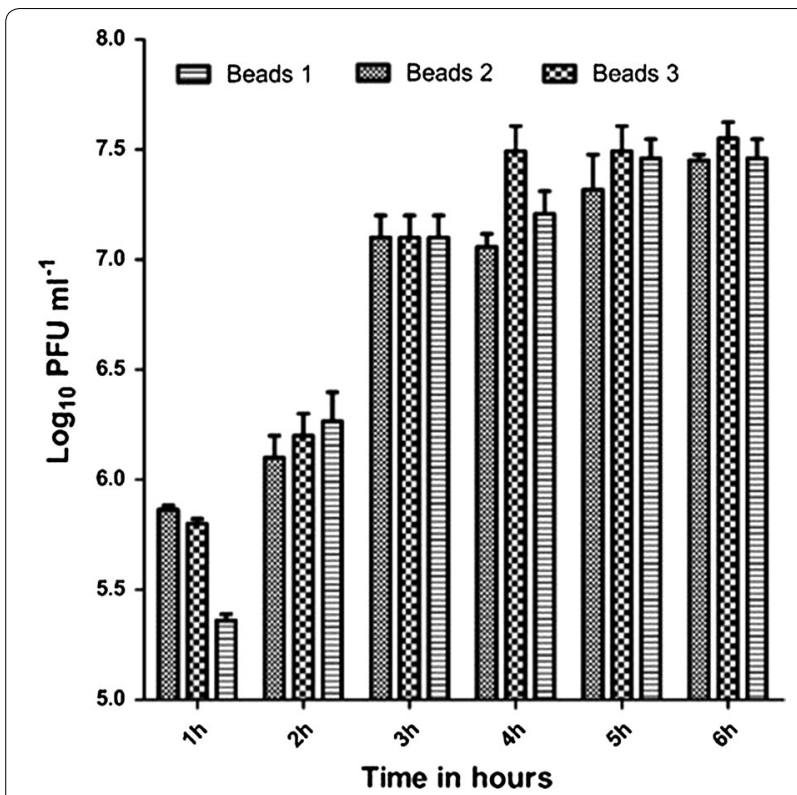

Fig. 3 In vitro $\log _{10}$ PFU mL $\mathrm{mL}^{-1}$ release of phages from chitosanalginate capsules during incubation in gastrointestinal fluid for $6 \mathrm{~h}$

the Tris-buffer based matrix of bead preparation 3 (titer reduction $2.3 \pm 0.14 \log _{10}$ PFU).

\section{Discussion}

Ensuring the stability of bacteriophages is a key concern in the design of any phage therapy delivery method. Phage encapsulation is a promising technique that employs feed compatible materials that have no detrimental effect on phage activity. We demonstrate that bead-encapsulation can control the delivery of bacteriophage ZCEC5 in simulated gastrointestinal fluid and protect the phage from harsh conditions encountered in the stomach and intestinal tract to enable therapeutic delivery to farm animals. The simple protocol produced an efficiency of encapsulation that approached $100 \%$ and conferred increased acid and thermal stability comparable to previous reports of phage encapsulation (Ma et al. 2008; Dini et al. 2012; Tang et al. 2013; Colom et al. 2017). Bead-encapsulated bacteriophages showed excellent stability with no loss in phage titer when stored at $4{ }^{\circ} \mathrm{C}$ for 8 weeks. We have reduced the concentration of alginate to $1.5 \%$ compared to previous reports of $2-2.2 \%$ without leakage of phage from the matrix (Kim et al. 2015; Ma et al. 2008). Bacteriophage administered to farm animals must tolerate the acidic environment of the stomach. Under simulated intestinal conditions, chitosan-alginate encapsulated phages showed greater stability than the non-encapsulated phages $(\mathrm{p}<0.01)$, with phage titer
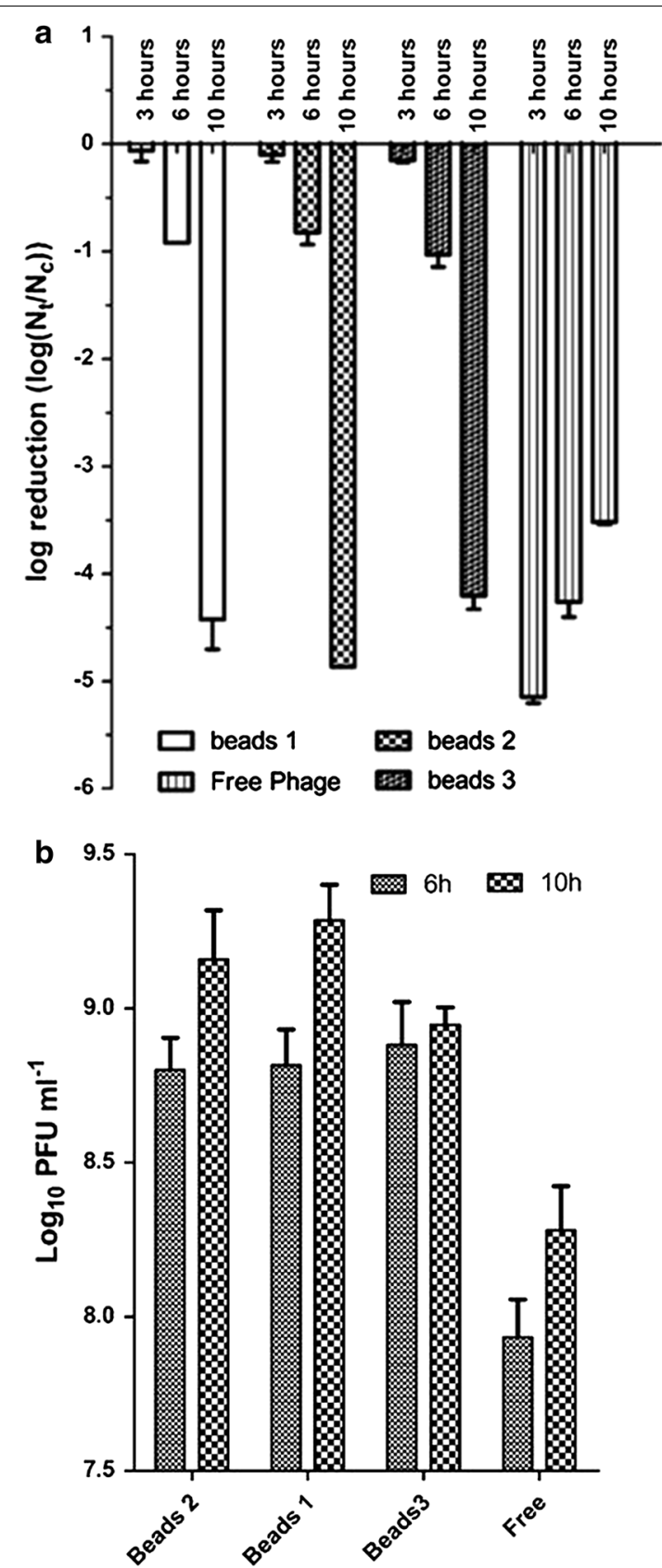

Fig. 4 a $\log _{10}$ reductions of E. coli O157:H7 incubated with encapsulated and non-encapsulated bacteriophages in gastrointestinal fluid at $37^{\circ} \mathrm{C}$ for $6 \mathrm{~h}$ and $10 \mathrm{~h}$. Nt stands for the number of E. coli O157:H7 after treatment with encapsulated and non-encapsulated bacteriophages at $\mathrm{MOI}=1$ and $\mathrm{Nc}$ represents the number of E. coli O157:H7 at the control state. All phage treatments produced significant falls in the viable count of E. coli O157:H7 ( $p$ value $<0.01$ ). b Bacteriophage titers ( $\log _{10}$ PFU) of non-capsulated and encapsulated phages after infecting E. coli $\mathrm{O} 157: \mathrm{H7}$ at $\mathrm{MOI}=1$ in gastrointestinal fluid for $6 \mathrm{~h}$ and $10 \mathrm{~h}$ 

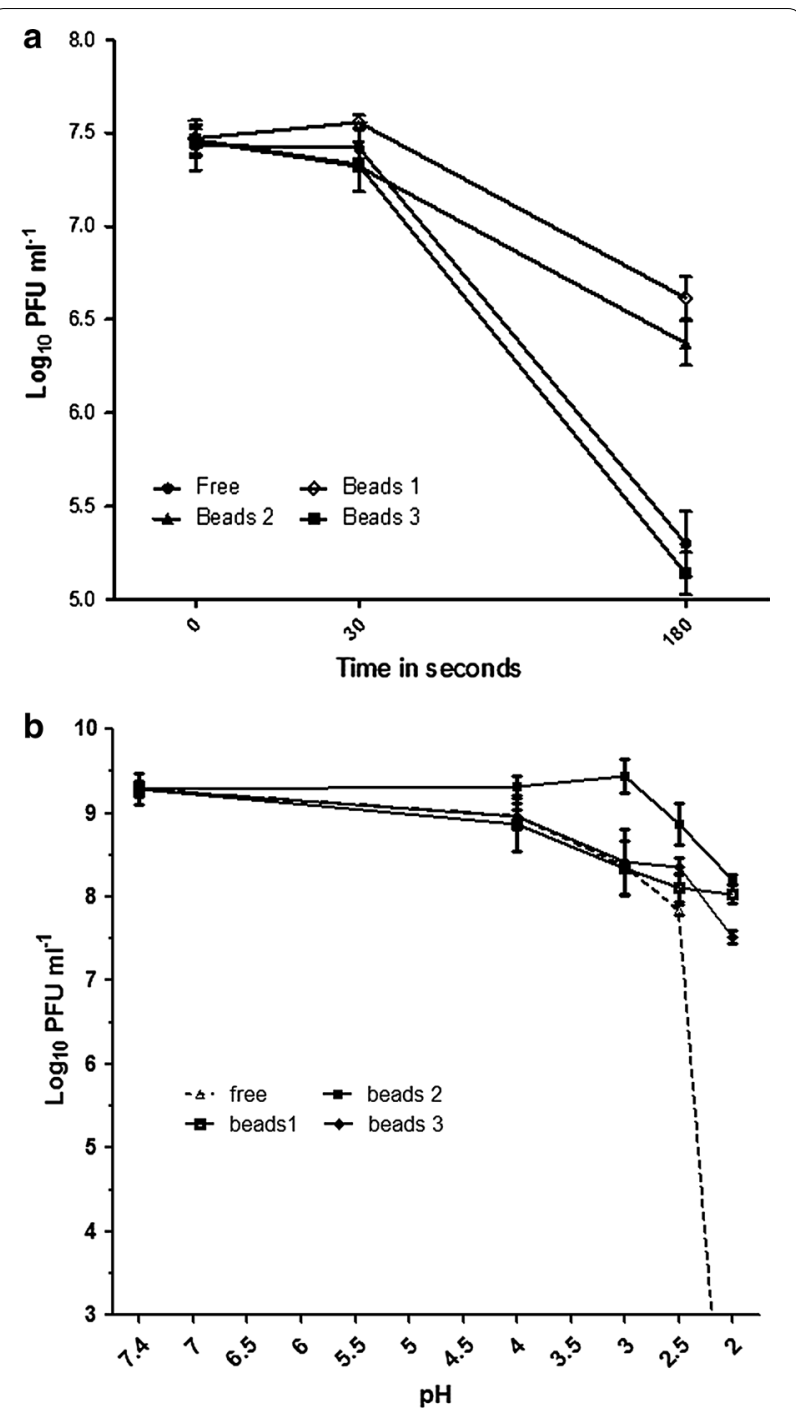

Fig. 5 a The stability of non-encapsulated and encapsulated bacteriophages against high temperature $\left(80^{\circ} \mathrm{C}\right)$ for $3 \mathrm{~min}$. $\mathbf{b} \mathrm{Low} \mathrm{pH}$ stability of the non-encapsulated and encapsulated bacteriophages $1 \mathrm{~h}$ at $37^{\circ} \mathrm{C}$. Limit of detection is $<10^{3} \mathrm{PFU} \mathrm{mL}{ }^{-1}$

losses of $0.95-1.3 \log _{10}$ PFU mL $\mathrm{mL}^{-1}$ after $1 \mathrm{~h}$ of incubation at $37{ }^{\circ} \mathrm{C}$ at $\mathrm{pH} 2$ compared to non-encapsulated phage that were extremely sensitive to acidic conditions at $\mathrm{pH}$ 2. Although limited, the phage titer reductions observed suggest that the chitosan-alginate capsule does not prevent acid diffusion to the core of the capsule, a process that will contribute to exposure time dependent phage release in simulated intestinal solutions. These observations are consistent with those reported previously using phage preparations against Vibrio vulnificus (Koo et al. 2000). The incorporation of honey and gelatin in the matrices of bead preparations 1 and 2 increased their ability to protect the bacteriophage payload; a strategy based on reducing the rate of proton diffusion by increasing the viscosity of the bead matrix (Tyrrell 1981; Ma et al. 2012).

The controlled time-dependent release of bacteriophage ZCEC5 was achieved using the chitosan-alginate multilayer bead, which forms a cross-linked matrix that is preferable to fixing phages in gel networks (Anal and Stevens 2005; Colom et al. 2017). The pore size of the carbohydrate polymer shell is less than $200 \mathrm{~nm}$ (Andresen et al. 1977), which is smaller than the ZCEC5 phage size $(223 \mathrm{~nm})$ and ensures the encapsulated phages are retained. Controlled release alters the dynamics of phage infection to delay the delivery of the active phage and extend the period in which the host bacteria are lysed. The prolonged activity of the bead-encapsulated phage is in contrast to the action of free phage that exhibit a reduction in the ability to kill the host and increase phage titers with time. The extended time of delivery and lysis activity, have the potential to reduce the development of phage resistance.

In conclusion, this study demonstrates the efficient protective effect of core matrix materials in chitosanalginate bead-encapsulated phage against inactivation by low $\mathrm{pH}$, and to sustain bacteriophage release and lysis activity over time. Bead-encapsulation represents a simple inexpensive phage oral drug delivery system suitable for on farm applications directed to control the intestinal colonization of zoonotic and pathogenic bacteria. Further studies have the potential to combine nutritional and therapeutic components with phages to aid recovery.

\section{Acknowledgements}

The authors like to thank all the members of Microbiology and Phage Therapy lab. This work is supported by Zewail City of Science and Technology.

\section{Author contributions}

AE-S and AA: primary responsibility for design of the work. AA, FA, AD and AE-S: substantial contributions to the design of the work and analysis. AE-S and IC contributed to the interpretation of the data. AA, IC, and AE-S: drafting the work and revising it critically for important intellectual content. All authors read and approved the final manuscript.

\section{Funding}

This research was supported by Zewail City of Science and Technology and the Science and Technology Development Fund (STDF), Grant Number 25543. This work was supported by the Biotechnology and Biological Sciences Research Council [Grant Number BB/GCRF-IAA/15].

Availability of data and materials

All data are available.

Ethics approval and consent to participate

Not applicable.

\section{Consent for publication}

Not applicable.

\section{Competing interests}

The authors declare that they have no competing interests. 


\section{Author details}

${ }^{1}$ Center for Microbiology and Phage Therapy, Zewail City of Science and Technology, October Gardens, 6th of October City, Giza 12578, Egypt. ${ }^{2}$ Center for X-Ray and Determination of Structure of Matter, Zewail City of Science and Technology, October Gardens, 6th of October, Giza 12578, Egypt. ${ }^{3}$ School of Biosciences, University of Nottingham, Sutton Bonington Campus, Loughborough, UK. ${ }^{4}$ Faculty of Environmental Agricultural Sciences, Arish University, North Sinai, Arish, Egypt.

Received: 14 March 2019 Accepted: 6 June 2019

Published online: 17 June 2019

\section{References}

Adams MH (1959) Methods of study of bacterial viruses. In: Adams MH (ed) Bacteriophages. Interscience Publication, New York

Akinkunmi E, Lamikanra A (2015) A study of the susceptibility of methicillin resistant coagulase-negative staphylococci isolated from faecal samples of children to commonly used antiseptic agents. Afr J Infect Dis 9:67. https://doi.org/10.4314/ajid.v9i2.10

Allan GG, Altman LC, Bensinger RE, Ghosh DK, Hirabayashi Y, Neogi AN, Neogi S (1984) Biomedical applications of chitin and chitosan. In: Zikakis JP (ed) Chitin, chitosan, and related enzymes. Elsevier, Amsterdam, pp 119-133

Anal AK, Stevens WF (2005) Chitosan-alginate multilayer beads for controlled release of ampicillin. Int J Pharm 290:45-54. https://doi.org/10.1016/j. ijpharm.2004.11.015

Andresen IL, Skipnes O, Smidsrod O, Ostgaard K, Hemmer PC (1977) Some biological functions of matrix components in benthic algae in relation to their chemistry and the composition of seawater. In: Arthur JC (ed) Cellulose chemistry and technology. ACS Publications, Washington, pp 361-381

Arndt D, Grant JR, Marcu A, Sajed T, Pon A, Liang Y, Wishart DS (2016) PHASTER: a better, faster version of the PHAST phage search tool. Nucleic Acids Res 44:W16-W21. https://doi.org/10.1093/nar/gkw387

Atterbury RJ, Connerton PL, Dodd CE, Rees CE, Connerton IF (2003) Isolation and characterization of Campylobacter bacteriophages from retail poultry. Appl Environ Microbiol 69:4511-4518. https://doi.org/10.1128/ AEM.69.8.4511-4518.2003

Bach SJ, McAllister TA, Veira DM, Gannon VPJ, Holley RA (2003) Effect of bacteriophage DC22 on Escherichia coli O157:H7 in an artificial rumen system (Rusitec) and inoculated sheep. Anim Res 52:89-101. https://doi. org/10.1051/animres:2003009

Belongia EA, MacDonald KL, Parham GL, White KE, Korlath JA, Lobato MN, Strand SM, Casale KA, Osterholm MT (1991) An outbreak of Escherichia coli 0157:H7 colitis associated with consumption of precooked meat patties. J Infect Dis 164:338-343. https://doi.org/10.1093/infdis/164.2.338

Bruttin A, Brussow H (2005) Human volunteers receiving Escherichia coli phage T4 orally: a safety test of phage therapy. Antimicrob Agents Chemother 49:2874-2878. https://doi.org/10.1128/AAC.49.7.2874-2878.2005

Choińska-Pulit A, Mituła P, Śliwka P, Łaba W, Skaradzińska A (2015) Bacteriophage encapsulation: trends and potential applications. Trends Food Sci Technol 45:212-221. https://doi.org/10.1016/j.tifs.2015.07.001

Colom J, Cano-Sarabia M, Otero J, Aríñez-Soriano J, Cortés P, Maspoch D, Llagostera M (2017) Microencapsulation with alginate/ $\mathrm{CaCO}_{3}$ : a strategy for improved phage therapy. Sci Rep 7:41441. https://doi.org/10.1038/ srep41441

Dini C, Islan GA, de Urraza PJ, Castro GR (2012) Novel biopolymer matrices for microencapsulation of phages: enhanced protection against acidity and protease activity. Macromol Biosci 12:1200-1208. https://doi.org/10.1002/ mabi.201200109

El-Shibiny A, El-Sahhar S, Adel M (2017) Phage applications for improving food safety and infection control in Egypt. J Appl Microbiol 123:556-567. https ://doi.org/10.1111/jam.13500

Fortini D, Fashae K, Garcia-Fernandez A, Villa L, Carattoli A (2011) Plasmidmediated quinolone resistance and -lactamases in Escherichia coli from healthy animals from Nigeria. J Antimicrob Chemother 66:1269-1272. https://doi.org/10.1093/jac/dkr085

Gbassi GK, Vandamme T (2012) Probiotic encapsulation technology: from microencapsulation to release into the gut. Pharmaceutics 4:149-163. https://doi.org/10.3390/pharmaceutics4010149
Gbassi GK, Vandamme T, Ennahar S, Marchioni E (2009) Microencapsulation of Lactobacillus plantarum spp in an alginate matrix coated with whey proteins. Int J Food Microbiol 129:103-105. https://doi.org/10.1016/j.ijfoo dmicro.2008.11.012

Ghosh P, Mandal S, Pal S, Bandyopadhyaya G, Chattopadhyay BD (2006) Development of bioconcrete material using an enrichment culture of novel thermophilic anaerobic bacteria. Indian J Exp Biol 44:336-339

Jassim SAA, Limoges RG (2014) Natural solution to antibiotic resistance: bacteriophages "The Living Drugs". World J Microbiol Biotechnol 30:2153-2170. https://doi.org/10.1007/s11274-014-1655-7

Jyothi NVN, Prasanna PM, Sakarkar SN, Prabha KS, Ramaiah PS, Srawan GY (2010) Microencapsulation techniques, factors influencing encapsulation efficiency. J Microencapsul 27:187-197. https://doi.org/10.3109/02652 040903131301

Karmali M, Petric M, Steele B, Lim C (1983) Sporadic cases of haemolytic-uraemic syndrome associated with faecal cytotoxin and cytotoxin-producing Escherichia coli in stools. Lancet 321:619-620. https://doi.org/10.1016/ S0140-6736(83)91795-6

Kim S, Jo A, Ahn J (2015) Application of chitosan-alginate microspheres for the sustained release of bacteriophage in simulated gastrointestinal conditions. Int J Food Sci Technol 50:913-918. https://doi.org/10.1111/ ijfs. 12736

Koo J, DePaola A, Marshall DL (2000) Effect of simulated gastric fluid and bile on survival of Vibrio vulnificus and Vibrio vulnificus phage. J Food Prot 63:1665-1669. https://doi.org/10.4315/0362-028X-63.12.1665

Kropinski AM, Mazzocco A, Waddell TE, Lingohr E, Johnson RP (2009) Enumeration of bacteriophages by double agar overlay plaque assay. Methods Mol Biol 501:69-76. https://doi.org/10.1007/978-1-60327-164-6_7

Lee KY, Heo TR (2000) Survival of Bifidobacterium longum immobilized in calcium alginate beads in simulated gastric juices and bile salt solution. Appl Environ Microbiol 66:869-873

Lillehaug D (1997) An improved plaque assay for poor plaque-producing temperate lactococcal bacteriophages. J Appl Microbiol 83:85-90. https ://doi.org/10.1046/j.1365-2672.1997.00193.x

Liu W, Jiao H, O'Connor M, Roelofs WL (2002) Moth desaturase characterized that produces both $\mathrm{Z}$ and $\mathrm{E}$ isomers of $\triangle 11$-tetradecenoic acids. Insect Biochem Mol Biol 32:1489-1495. https://doi.org/10.1016/S0965 $-1748(02) 00069-3$

Ma Y, Pacan JC, Wang Q, Xu Y, Huang X, Korenevsky A, Sabour PM (2008) Microencapsulation of bacteriophage felix $\mathrm{O} 1$ into chitosan-alginate microspheres for oral delivery. Appl Environ Microbiol 74:4799-4805. https://doi.org/10.1128/AEM.00246-08

Ma Y, Pacan JC, Wang Q, Sabour PM, Huang X, Xu Y (2012) Enhanced alginate microspheres as means of oral delivery of bacteriophage for reducing Staphylococcus aureus intestinal carriage. Food Hydrocoll 26:434-440. https://doi.org/10.1016/j.foodhyd.2010.11.017

Marcó MB, Moineau S, Quiberoni A (2012) Bacteriophages and dairy fermentations. Bacteriophage 2:149-158. https://doi.org/10.4161/bact.21868

McCallin S, Alam Sarker S, Barretto C, Sultana S, Berger B, Huq S, Krause L, Bibiloni R, Schmitt B, Reuteler G, Brüssow H (2013) Safety analysis of a Russian phage cocktail: from MetaGenomic analysis to oral application in healthy human subjects. Virology 443:187-196. https://doi.org/10.1016/j. virol.2013.05.022

Mcknight CA, Ku A, Goosen MFA, Sun D, Penney C (1988) Synthesis of chitosan-alginate microcapsule membranes. J Bioact Compat Polym 3:334-355. https://doi.org/10.1177/088391158800300402

Munot K, Kotler DP (2016) Small intestinal infections. Curr Gastroenterol Rep 18:1-9. https://doi.org/10.1007/s11894-016-0502-4

Neil KP, Biggerstaff G, MacDonald JK, Trees E, Medus C, Musser KA, Stroika SG, Zink D, Sotir MJ (2012) A novel vehicle for transmission of Escherichia coli 0157:H7 to humans: multistate outbreak of E. coli O157:H7 infections associated with consumption of ready-to-bake commercial prepackaged cookie dough-United States, 2009. Clin Infect Dis 54:511-518. https://doi. org/10.1093/cid/cir831

O'Flynn G, Ross RP, Fitzgerald GF, Coffey A (2004) Evaluation of a cocktail of three bacteriophages for biocontrol of Escherichia coli O157:H7. Appl Environ Microbiol 70:3417-3424. https://doi.org/10.1128/ AEM.70.6.3417-3424.2004

Oliveira A, Ribeiro HG, Silva AC, Silva MD, Sousa JC, Rodrigues CF, Melo LDR, Henriques AF, Sillankorva S (2017) Synergistic antimicrobial interaction 
between honey and phage against Escherichia coli biofilms. Front Microbiol 8:2407. https://doi.org/10.3389/fmicb.2017.02407

Pavlickova S, Dolezalova M, Holko I (2015) Resistance and virulence factors of Escherichia coli isolated from chicken. J Environ Sci Health B 50:417-421. https://doi.org/10.1080/03601234.2015.1011959

Raya RR, Oot RA, Moore-Maley B, Wieland S, Callaway TR, Kutter EM, Brabban AD (2011) Naturally resident and exogenously applied T4-like and T5-like bacteriophages can reduce Escherichia coli 0157. Bacteriophage 1:15-24. https://doi.org/10.4161/bact.1.1.14175

Sarker SA, McCallin S, Barretto C, Berger B, Pittet AC, Sultana S, Krause L, Huq S, Bibiloni R, Bruttin A, Reuteler G, Brüssow H (2012) Oral T4-like phage cocktail application to healthy adult volunteers from Bangladesh. Virology 434:222-232. https://doi.org/10.1016/j.virol.2012.09.002

Sudarshan NR, Hoover DG, Knorr D (1992) Antibacterial action of chitosan. Food Biotechnol 6:257-272. https://doi.org/10.1080/08905439209549838

Summers WC (2001) Bacteriophage therapy. Annu Rev Microbiol 55:437-451

Taha OA, Connerton PL, Connerton IF, El-Shibiny A (2018) Bacteriophage ZCKP1: a potential treatment for Klebsiella pneumoniae isolated from diabetic foot patients. Front Microbiol 9:2127. https://doi.org/10.3389/ fmicb.2018.02127

Tang Z, Huang X, Baxi S, Chambers JR, Sabour PM, Wang Q (2013) Whey protein improves survival and release characteristics of bacteriophage Felix $\mathrm{O} 1$ encapsulated in alginate microspheres. Food Res Int 52:460-466. https://doi.org/10.1016/j.foodres.2012.12.037

Tanji Y, Shimada T, Fukudomi H, Miyanaga K, Nakai Y, Unno H (2005) Therapeutic use of phage cocktail for controlling Escherichia coli O157:H7 in gastrointestinal tract of mice. J Biosci Bioeng 100:280-287. https://doi. org/10.1263/jbb.100.280

Tóthová L, Bábíčková J, Celec P (2012) Phage survival: the biodegradability of M13 phage display library in vitro. Biotechnol Appl Biochem 59:490-494. https://doi.org/10.1002/bab.1050

Tyrrell HJV (1981) Diffusion and viscosity in the liquid phase. Sci Prog 67:271293. https://doi.org/10.2307/43420528

Verstraete MA, Denys RM, Van Minnebruggen K, Hertelé S, De Waele W (2013) Determination of CTOD resistance curves in side-grooved Single-Edge Notched Tensile specimens using full field deformation measurements. Eng Fract Mech 110:12-22. https://doi.org/10.1016/j.engfracmec h.2013.07.015

Wellington EM, Boxall AB, Cross P, Feil EJ, Gaze WH, Hawkey PM, Johnson-Rollings AS, Jones DL, Lee NM, Otten W, Thomas CM, Williams AP (2013) The role of the natural environment in the emergence of antibiotic resistance in Gram-negative bacteria. Lancet Infect Dis 13:155-165. https://doi. org/10.1016/S1473-3099(12)70317-1

Xie H, Zhuang X, Kong J, Ma G, Zhang H (2005) Bacteriophage Esc-A is an efficient therapy for Escherichia coli 3-1 caused diarrhea in chickens. J Gen Appl Microbiol 51:159-163. https://doi.org/10.2323/jgam.51.159

\section{Publisher's Note}

Springer Nature remains neutral with regard to jurisdictional claims in published maps and institutional affiliations.

\section{Submit your manuscript to a SpringerOpen ${ }^{\circ}$ journal and benefit from:}

- Convenient online submission

- Rigorous peer review

- Open access: articles freely available online

- High visibility within the field

- Retaining the copyright to your article

Submit your next manuscript at springeropen.com 